\section{Stimulation of Glutamate Uptake by NADH and NADPH in Intact Cells of Escherichia coli Mutant Defective in $\mathrm{Mg}^{2+}, \mathrm{Ca}^{2+}$-ATPase}

\author{
Shigeo Murakawa and Takeshi Takahash \\ Department of Agricultural Chemistry, \\ Tokyo Noko University, \\ Fuchu, Tokyo 183, Japan \\ Received May 15, 1978
}

Previously, we have reported the marked stimulation of $\mathrm{C}_{4}$-dicarboxylate transport system in Escherichia coli membrane vesicles by external NADH. ${ }^{\text {" }}$ NADH is generally reported, however, to be a poor electron donor for transport in E. coli membrane vesicles and is supposed to be impermeable (see reference 2)). Furthermore, Futai ${ }^{3}$ has reported that only internally generated NADH stimulates proline transport in E. coli vesicles. This communication demonstrates the stimulation of $\mathrm{L}$ glutamate uptake in intact cells of an unc mutant of $E$. coli by NADH and NADPH added.

E. coli W2252 (met $\left.{ }^{-}\right)$and its UV-induced mutant strain PA5 ( met $^{-}$, unc $^{-}$), defective in membrane bound $\mathrm{Mg}^{2+}, \mathrm{Ca}^{2+}$-ATPase were used. The mutant was selected for neomycinresistance and inability to grow on non-fermentable carbon sources. The unc gene was co-transduced by Pl-transduction with ilv gene at a frequency of about 0.6 . The precise methods and the nature of the mutant will be published elsewhere. Cells were grown aerobically at $30^{\circ} \mathrm{C}$ in a minimal medium with $0.3 \%$ glycerol and $0.2 \%$ succinate, and harvested at late-log phase, washed 3 times and resuspended in $0.05 \mathrm{M}$ potassium phosphate buffer, $\mathrm{pH} 7.0$ with $1 \mathrm{~mm} \mathrm{MgSO}_{4}$. Transport assays were performed as described previously ${ }^{\not,}$ except that cells of about $0.5 \mathrm{mg}$ protein $/ \mathrm{ml}$ were incubated in $0.05 \mathrm{M} \mathrm{K}$-phosphate buffer, pH 7.0 with $1 \mathrm{mM} \mathrm{MgSO}_{4}$, trace minerals, $100 \mu \mathrm{g} / \mathrm{ml}$ of chloramphenicol and $14.8 \mu \mathrm{M}$
L-glutamate-U- ${ }^{14} \mathrm{C}$, and that $0.1 \mathrm{M} \mathrm{LiCl}, \mathrm{pH} 7.0$ with $1 \mathrm{mM}$ of $p$-hydroxymercuribenzoate was used to stop the reaction and washing after membrane-filtration.

As shown in Table I, addition of NADH or NADPH stimulated the initial rate of glutamate uptake by PA5 about 40 to 60 fold over the control without energy source. Surprisingly, NADP ${ }^{+}$which could not be a direct electron donor also stimulated the glutamate uptake as about the same extent as that by Dlactate, one of the most effective physiological electron donor in E. coli. These results suggest the incorporation of $\mathrm{NAD}^{+}$and $\mathrm{NADP}^{+}$into the cells, as well as their reduced forms.

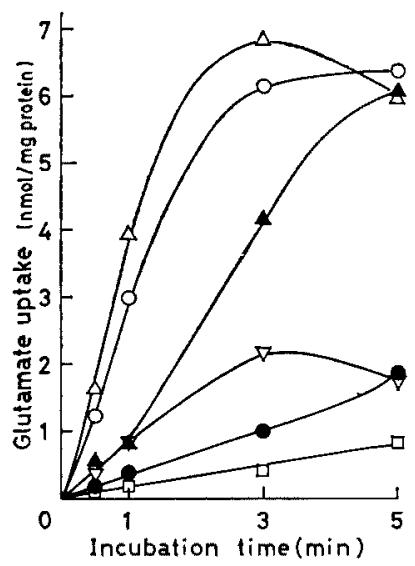

Fig. 1. Uptake of Glutamate by Intact Cells of PA5. The cells were incubated at $25^{\circ} \mathrm{C}$ with $10 \mathrm{~mm}$ of each energy source: $\square$, none; $-\mathrm{NAD}^{+} ; 0, \mathrm{NADH}$; $\Delta, \mathrm{NADP}^{+} ; \triangle$, NADPH; $\nabla$, D-lactate.

Figure 1 shows the time course of glutamate uptake in PA5. Addition of $\mathrm{NADP}^{+}$resulted in marked stimulation of glutamate uptake after a slight lag time. $\mathrm{NAD}^{+}$also stimulated the glutamate uptake after a more prolonged lag time. $\mathrm{NADP}^{+}$incorpolated might be reduced by L-glutamate dehydrogenase in the presence of glutamate accumulated by facilitated diffusion and/or endogenous energization, and then, the NADPH produced stimulates further uptake of glutamate. It seems likely that NADH or NADPH oxidized is re-reduced by metabolism of glutamate incorporated, and this oxidation-reduction cycle 


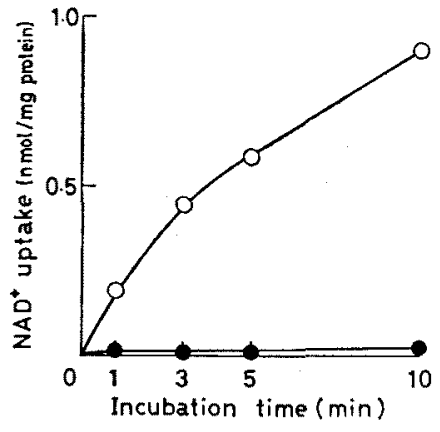

FIG. 2. Uptake of $\mathrm{NAD}^{+}$by Intact Cells of PA5. The cells were incubated at $25^{\circ} \mathrm{C}$ with (carbonyl- ${ }^{14} \mathrm{C}$ )$\mathrm{NAD}^{+}(23.6, \mathrm{M}$, from Amersham) in the presence (O) or absence ( ) of $10 \mathrm{~mm}$ D-glucose.

effectively facilitate the uptake and metabolism of glutamate. Accordingly, $\mathrm{NAD}^{+}$or $\mathrm{NADP}^{+}$ naturally scarcely stimulated the glutamate uptake by membrane vesicles devoid of glutamate metabolism.

The glutamate uptakes shown above were strongly inhibited by respiration poisons and uncouplers of oxidative phosphorylation, therefore these uptakes are probably energized by electrochemical potential differences like those in membrane vesicles.

As shown in Fig. 2, ${ }^{14} \mathrm{C}-\mathrm{NAD}^{+}$was incorporated into the cells only in the presence of energy source. This may indicate the presence of some specific $\mathrm{NAD}^{+}$transport system in E. coli. So marked stimulation of glutamate uptake as in PA5 was not observed in W2252, however, similar glucose-driven $\mathrm{NAD}^{+}$uptake activity (near about a half of that by PA5) was also detected in W2252. The difference in stimulation of glutamate uptake between the parent and mutant strains may probably be attributed to some altered induction of the uptake system, cellular metabolism and/or membrane structure resulted from the lower growth rate and yield of the unc mutant. To
Table 1. Effect of Eneroy Sources on Glutamate Uptake by InTaCt Cells of PA5 Reactions were carried out at $25^{\circ} \mathrm{C}$ for $1 \mathrm{~min}$.

\begin{tabular}{lc}
\hline \multicolumn{1}{c}{$\begin{array}{c}\text { Energy source } \\
(10 \mathrm{mM})\end{array}$} & $\begin{array}{c}\text { Glutamate uptake } \\
(\text { nmol/min/mg protein) }\end{array}$ \\
\hline None & 0.10 \\
NAD $^{+}$ & 0.29 \\
NADP $^{+}$ & 0.63 \\
NADH & 3.80 \\
NADPH & 5.63 \\
L-AA + PMS & 3.15 \\
D-Lactate & 0.83 \\
\hline
\end{tabular}

Abbreviations: L-AA, L-ascorbic acid; PMS, phenazine methosulfate.

confirm these assumptions, search for optimal conditions of induction and experiments with isogenic unc transductant and revertant strains will be needed. In this regard, Lombardi et al. ${ }^{4}$ reported the stimulation of $\mathrm{O}_{2}$ uptake by NADH in intact cells of $E$. coli.

Although little is known about the permeability of NADH in $E$. coli, $\mathrm{NADH}$ has been used for studying several membrane functions as an impermeable electron donor. ${ }^{2,3,5)}$ It is important to elucidate the permeation system(s) for $\mathrm{NADH}$ and $\mathrm{NAD}^{+}$in considering membrane problems such as orientation, distribution of membrane proteins and mechanism of active transport system.

\section{REFERENCES}

1) S. Murakawa, K. Izaki and H. Takahashi, Agric. Biol. Chem., 37, 1905 (1973).

2) W. N. Konings, Adv. Microb. Physiol., 15, 175 (1977)

3) M. Futai, J. Bacteriol., 120, 861 (1974).

4) F. J. Lombardi, J. P. Reeves, S. A. Short and H. R. Kaback, Ann. N. Y. Acad. Sci., 227, 312 (1974).

5) L. W. Adler and B. P. Rosen, J. Bacteriol., 129, 959 (1977). 